\title{
Jaak Põldmäe 75
}

Mihhail Lotman

On November 6, 2017, Jaak Põldmäe (1942-1979) would have become seventy-five years old. His life was short and difficult. Põldmäe was born in Tartu during the German occupation, and his father was arrested in 1945. In 1949, he and his mother were also arrested as family members of an "enemy of the people" and deported to the Omsk Oblast in Siberia. That deportation, as well as learning Russian in the schools of Omsk, had a heavy impact on his mind as a child, and can explain many of his life-long character traits as a man.

In 1955, more than a year after the death of Stalin, the family was allowed to return to Estonia. Instead of returning to Tartu, they relocated to the small nearby town of Elva. After graduating from high school Põldmäe was admitted to the University of Tartu. In high school and at university he stood out for his multifaceted academic talents and was able to continue his work as a postgraduate student, supervised by the renowned semiotician and linguist Vyacheslav V. Ivanov. During his studies, Põldmäe immersed himself into the Russian methods of statistical versification, but Ivanov inspired him to work on the axiomatic approach to versification systems.

Põldmäe’s enthusiasm and working capacity were admirable. In just a few years he had managed to achieve more in Estonian verse studies than all of his predecessors combined. Unfortunately, however, his novel ideas evoked controversial reactions from the close-minded scholars, while his results and international recognition aroused their envy. He was a man of principle, which sometimes manifested as stubbornness, and was often met with ill will by colleagues, who in-turn often attempted to obstruct his scholarly career. Facing this hostile environment, Põldmäe developed self-destructive tendencies. The persecution continued even after his death, as literary critic Mart Mäger tried to dissolve his lifework in two lengthy papers $(1981,1982)$. Ain Kaalep, an outstanding Estonian academician, poet, translator and poetry theorist, defended him (1981), as did the author of this text (Lotman 1982). The overview of Põldmäe's lifework was presented in a collective paper (Gasparov, Lotman, Rudnev, Tarlinskaja 1987), which can now be read in English in the abovegiven translation by Igor Pilshchikov and Marina Tarlinskaja together with their emendations and comments. 


\section{References}

Gasparov, Mikhail Leonovich; Lotman, Mihhail; Rudnev, Pyotr; Tarlinskaja, Marina 1987. Problemy stikhovedenija v rabotakh Ja. R. Põldmäe [Approaches to verse theory in the works of Ja. R. Põldmäe]. In: Studia metrica et poetica [V]: Poeetiliste süsteemide dünaamika / Dinamika poeticheskikh sistem [The Dynamics of Poetic Systems] (Acta et Commentationes Universitatis Tartuensis 780). Tartu: The University of Tartu, 99-115.

Kaalep, Ain 1981. Kahjuks pigem arutus kui arutlus [Alas: a concussion, rather than a discussion]. In: Keel ja Kirjandus 9, 551-555.

Leino, Pentti 1985. "Eesti värsiõpetuse" võimalused [Prospects for Estonian Verse Theory]. In: Looming 8, 1118-1132.

Lotman, Mihhail 1982. Jaak Põldmäe värsiõpetus ja selle arutelu [Jaak Põldmäe’s verse theory and the discussions surrounding it]. In: Looming 7, 983-991.

Mäger, Mart 1981. Arutlusi eesti värsiõpetuse üle [On the discussions of Estonian verse theory]. In: Looming 7, 1003-1023.

Mäger, Mart 1984. Värsiõpetuse õppetunnid [Lessons of verse theory]. In: Looming 2, 249-266. 